\title{
From Union Citizen to Third-Country National: Brexit, the UK Withdrawal Agreement, No-Deal Preparations and Britons Living in the European Union
}

\author{
Gillian More*
}

\section{Introduction}

Brexit, including over three years of uncertainty leading up to Brexit on 31 January 2019 , has had a profound effect on the lives of the approximately 3 million EU citizens living in the UK and 1.2 million UK nationals ${ }^{1}$ living in the EU Member States. For both groups of citizens, the UK's withdrawal from the EU means their rights under EU law are withdrawn while they are exercising them. This is an unprecedented situation and a major development in the history of Union citizenship ("EU citizenship").

Brexit for UK nationals means they become third-country nationals and collectively lose their EU citizenship. This chapter focusses on the specific position of UK nationals (referred to interchangeably as either UK nationals or Britons) who live and/or work in the EU(and who do not have the nationality of another Member State and thereby lose EU citizenship). What happens in legal terms to these former EU citizens still living in the EU?

The transformation of Britons into non-EU citizens in fact takes place in two stages: in a first stage, from 1 February 2020 when the UK ceases to be a Member State, all UK nationals lose the political rights of EU citizenship (see further below). ${ }^{2}$ The Withdrawal Agreement allows however other rights of EU citizenship to be retained during the transition period: all UK nationals

* Legal Officer, DG GROW, European Commission. Affiliated Member, Institute of European Law, KU Leuven. The information and views set out in this chapter are those of the author and do not necessarily reflect the official opinion of the European Commission.

1 For a discussion of the size of the UK population in the EU, see, Benton, M. (2017). Safe or Sorry: Prospects for Britons in the EU after Brexit. Migration Policy Institute 2017, 6-11.

2 These rights are excepted from the effect of the transition period by Article 127(1)(b) of the Withdrawal Agreement on the withdrawal of the United Kingdom of Great Britain and 
continue to enjoy the rights of free movement and residence in other Member States during this time. In the second stage, at the end of the transition (in principle $3_{1}$ December 2020), these rights will end. ${ }^{3}$ The provisions of Part Two of the Withdrawal Agreement then kick in fully to protect only those citizens and their family members within its scope. ${ }^{4}$ As this contribution will set out, only certain rights are however protected by the Agreement.

The chapter is divided into four parts. First, it reminds the reader of the concept of EU citizenship and its associated rights: what exactly do UK nationals lose? Second, it considers the Withdrawal Agreement: what has the process been; what is its scope; what rights does it protect for UK nationals living and/ or working in the EU? Third, the preparations made by the EUunder the NoDeal scenario for the sudden default of UK citizens to third-country national status are put under the lens. The fourth section reflects more broadly on the withdrawal of EU citizenship: who has the duty to protect the citizens whose EU citizenship is being withdrawn; what rights must be protected; and what should the process look like?

The specific rights that may eventually be given to UK nationals residing and/or working in the EU under a new UK-EU relationship are, at the time of writing, unknown. ${ }^{5}$ This issue is not therefore discussed. The position of non-mobile UK nationals, who remain in the UK, is out of scope of this contribution too.

EU Citizenship - the Concept - the Rights - Its Evolution

The Maastricht Treaty established both the European Union and the concept of EU citizenship. EU citizenship was part of the creation of a "People's Europe":- showing to citizens that the nascent Union offered more than merely the possibility to participate in the (single) market. ${ }^{6}$ In addition, a new label, "Union citizen" or "EU citizen" was invented that went beyond the "privileged

Northern Ireland from the European Union and the European Atomic Energy Community, OJ $C_{384}$ I, 12.11.2019, p. 1-184 (hereinafter, "the Withdrawal Agreement").

3 Article 132(1) provides that the transition period may before 1 July 2020 be extended for up to 1 or 2 years.

4 Article 126 of the Withdrawal Agreement.

5 An outline of what is foreseen as regards movement of citizens can be found in Part IX "Mobility" of the Political Declaration setting out the framework for the future relationship between the European Union and the United Kingdom, $O J C_{384}, 12.11 .19$, p. 178.

6 A People's Europe: Reports from the ad hoc Committee (Adonnino Report), Bull-EC Supp 7 / 85 . 
foreigner" status that nationals from Member States had hitherto enjoyed in a host Member State. ${ }^{7}$ The Union citizen was defined as every person holding the nationality of a Member State and a set of citizenship rights was laid down by the new Treaty.

The core element of EU citizenship, when introduced, was in fact an already known set of rights: the right to move and reside within the territory of all Member States. What was new was that such rights were conferred by primary law on all Union citizens (although subject to limitations and conditions), regardless of economic activity. There were also political rights, which in part restated what already existed pre-Maastricht: the right for EU citizens to vote and stand in European Parliament elections, including while residing in another Member State; a new right to vote and stand in local elections in the Member State of residence; and the right to petition the European Parliament, another already-existing right. To this group of political rights, the Lisbon Treaty later added the right to launch a European Citizen's initiative - a right intended to promote EU citizens' participation in the democratic life of the Union. ${ }^{8} \mathrm{EU}$ citizens were also (by the Maastricht Treaty) conferred with the right to consular protection by any Member State when unrepresented in a third country outside of the EU. In addition, institutional rights, aimed at reinforcing relations with EU institutions, were listed: the right to apply to the European Ombudsman; to which the Amsterdam Treaty added the right to correspond with the EU institutions in one's own language.

While not formally part of the list of EU citizenship rights, the guarantee of non-discrimination on grounds of Member State nationality is a fundamental, constitutional aspect of EU citizenship. ${ }^{9}$

At the time of introduction of EU citizenship, many writers demonstrated scepticism towards the concept. Everson underlined the difficulty of creating a bond of citizenship and allegiance between an individual and a transnational group of states. While EU citizenship was a "progressive concept" and could be a "dynamic notion", Everson doubted whether what was essentially still a market or consumer status could do this. ${ }^{10}$ Jessurun d'Oliveira considered the concept as largely symbolic, lacking coherence and with little new

7 Jessurun d'Oliveira, H.U. (1994). Citizenship: Its meaning, Its Potential. In: Dehousse, ed., European After Maastricht: An Ever Closer Union? Munich: CH Beck, p. 127.

8 Recital 1 of Regulation (EU) 2019/788 on the European Citizens' Initiative, OJ L 130, 17.5.2019, p. 55 .

9 Muir, E. (2018). EU equality law: the first fundamental rights policy of the EU. Oxford: Oxford University Press, p. 36.

10 Everson, M. (1995). The Legacy of the Market Citizen. In: Shaw and More, eds., New Legal Dynamics of European Union. Oxford: Clarendon Press, pp. 89-9o. 
content. Moreover, due to its link to the nationality of a Member State, EU citizenship created a demarcation line between those who "belonged" and those who did not. In his view it would have been both more cohesive and more rational in policy terms to forge EU citizenship for resident aliens as well. ${ }^{11}$

Since its introduction, EU citizenship has evolved considerably. Its definition was amended by the Amsterdam Treaty to underline that it complements and does not replace national citizenship. It is reinforced by a section on "Citizens' rights" in the Charter of Fundamental Rights of the EU. It is supported by a body of secondary legislation, ${ }^{12}$ which in various ways shapes its content and direction. The Court of Justice has contributed to the development of EU citizenship through its judgments: in its heyday the Court established that EU citizenship was "destined to be the fundamental status of nationals of the Member States"; ${ }^{13}$ more recently, reacting to a political environment hostile to mobile EU citizens accessing social welfare, the Court reined in the equal treatment rights of EU citizenship. ${ }^{14}$ Public opinion surveys show that EU citizenship is a concept that the European public embraces. ${ }^{15}$ Through the ECI and other civil society initiatives, EU citizenship provides a framework for European action not just from the top down but also from the bottom up. ${ }^{16}$ It has become a product not only of a process of polity-building beyond the state, but also of a move away from a predominantly state-centred conception of citizenship. ${ }^{17}$

11 Jessurun d'Oliveira, H.U. (1994), cit., p. 147.

12 Most notably, Directive 2004/38/EC on the right of citizens of the Union and their family members to move and reside freely within the territory of the Member State, OJ L 158 , 30.4.2004, p. 77; Directive 94/80/EC on the right to vote and to stand as a candidate in municipal elections, $O_{J} L_{3} 68$, 31.12.1994, p. 38; Directive 93/109 on the exercise of the right to vote and stand as a candidate in elections to the European Parliament for citizens of the Union residing in a Member State of which they are not nationals European Parliament elections OJ L 329, 30.12.1993, p. 34; Directive (EU) 2015/637 on the coordination and cooperation measures to facilitate consular protection for unrepresented citizens of the Union in third countries and repealing Decision 95/553/EC, $O J L$ 106, 24.4.2015, p. 1.

13 Court of Justice, judgment of 20 September 2001, case C-184/99, Grzelczyk, para. 31.

14 Martinsen, D.S. and others. (2018). ECJ judges read the morning papers. Explaining the turnaround of European citizenship jurisprudence. Journal of European Public Policy 25 (10), pp. 1422-1441.

15 Standard Eurobarometer 91 (published in August 2019) showed that in all 28 Member States, more than half of respondents felt that they were citizens of the EU. Across the EU, $73 \%$ felt this way.

16 Venables, T. (2016). The UK Referendum on Membership of the EU: One Choice Hides Another - to Keep or Give up European Citizenship. ECIT Foundation.

17 Shaw, J. (2018). EU Citizenship: Still a Fundamental Status? EUI Working Papers RSCAS $2018 / 14$, p. 3 . 
The personal scope of EU citizenship remains however firmly linked to nationality of a Member State. ${ }^{18}$ Concern about the loss of rights Brexit entails has triggered a massive wave of applications from UK citizens for other Member State nationalities in order to conserve their EU citizenship. ${ }^{19}$ UK nationals in the Netherlands initiated litigation - judged premature by the national appeal court - to challenge the loss of EU citizenship. ${ }^{20}$ The MEP, Charles Goerens, put forward the possibility of creating associate EU citizenship for nationals of a former Member State; ${ }^{21}$ a European Citizens' Initiative ("ECI") was launched to ask for the creation of "Permanent EU Citizenship"; ${ }^{22}$ and a citizens' lobby group suggested a "Green Card" as a way to maintain free movement rights after Brexit for both EU citizens and UK nationals with permanent residence rights. ${ }^{23}$ In April 2020 a direct action challenging the removal of EU citizenship rights upon the UK's departure from the EU was lodged before the General Court of the EU. ${ }^{24}$ Brexit has paradoxically brought the concept of EU citizenship alive! ${ }^{25}$

Yet, despite the attempts by UK nationals to find a way to retain EU citizenship, the Brexit negotiations between the EU and the UK made clear there was no panacea for the loss of EU citizenship pursuant to Brexit. Article 50(3) TEU is the mechanism by which EU citizenship is removed. It provides that the Treaties shall cease to apply to the State, which has notified its withdrawal from the EU under the terms of Article 50 TEU. Thus, when the Withdrawal Agreement takes effect, the UK ceases to be a Member State and persons with UK nationality thereby no longer fulfill the condition in Article 20 TFEU to have EU citizenship - "nationality of a Member State". In this way the rights of

18 Kostakopoulou, D. (2014). European Union citizenship and Member State nationality: rethinking the link? In: Konopacki, ed., Europe in the time of crisis. Łódź/ Kraków: Wydawnictwo Uniwersytetu Łódzkiego, p. 71.

19 House of Commons Library Briefing, Brexit and European Citizenship, 6 July 2018, p. 35.

20 De Staat der Nederlanden \& de Gemeente Amsterdam v Brexpats Hear Our Voice, Gerechtshof Amsterdam, 20 June 2018, ECLI:NL:GHAMS:2018:2009.

21 European Parliament Committee on Constitutional Affairs (2016). Amendments to draft report on "Possible evolutions of and adjustments to the current institutional set-up of the European Union". 9 November 2016.

22 Available at https://www.eucitizen2017.org.

23 "European Green Card proposed as solution", available at https://neweuropeans.net/article/2628/european-green-card-proposed-solution.

24 Available at https:/www.thelondoneconomic.com/politics/exclusive-uk-campaignersfile-case-to-prove-withdrawal-agreement-cannot-remove-eu-citizenship/27/04/

25 Jessurun d'Oliveira, H.U. (2018). Brexit, Nationality and Union Citizenship: bottom up. EUI Working Papers RSCAS 2018/49. 
EU citizenship listed in Article 2O(2) TFEU previously enjoyed by UK nationals simply fall away. Other key rights for individuals in the EU Treaties, which depend on having nationality of a Member State, such as the rights of work and establishment in another Member State and the right to provide cross-border services, are also lost by virtue of the effect of Article 50 TEU.

\section{2 Loss of EU Citizenship and the Withdrawal Agreement}

From the outset of the discussions concerning Brexit, the EU and the UK government stated their commitment to protecting the rights of citizens affected by Brexit - both EU citizens in the UK and UK nationals in the EU. The protection of citizens' rights was one of the central planks of the Withdrawal Agreement. A position paper published by the European Commission's Taskforce 50 on 12 June 2017 set out its objective as follows:

..to protect the rights of EU27 citizens, UK nationals and their family members who ... have enjoyed rights relating to free movement under Union law, as well as rights which are in the process of being obtained and the rights the enjoyment of which will intervene at a later date[for example pensions rights]. ${ }^{26}$

The paper set out essential principles for the start of the withdrawal negotiations with the UK, stating that, among others, the following principle should apply:

the same level of protection as set out in Union law at the date of withdrawal of EU27 citizens in the UK and of UK nationals in EU27 including the right to acquire permanent residence after a continuous period of 5 years of legal residence ...

As the negotiations commenced and a joint EU-UK position was agreed in the December 2017 Joint Report, ${ }^{27}$ the commitment of the earlier position paper

26 European Commission (2017). TaskForce5o Position Paper on "Essential Principles on Citizens' Rights", 12 June 2017.

27 Joint Report of the negotiators of the European Union and the United Kingdom Government on progress during phase 1 of negotiations under Article 50 TEU on the United Kingdom's orderly withdrawal from the European Union, TF5o (2017) 19 Commission to EU 27. 8 December 2017, available at https:/ec.europa.eu/commission/ sites/beta-political/files/joint_report.pdf. 
narrowed: the aim became "protecting the effective exercise of rights derived from EU law and based on past life choices". As the discussion below will show, the new focus on "past life choices", in the case of UK nationals in the EU, became a limitation.

Laffan describes the key strengths of the Union in the withdrawal negotiations as the way it framed the Brexit negotiations and the method it developed: a so-called "Brexit toolkit". ${ }^{28}$ In the context of citizens' rights, "protection of past life choices" and reciprocal protection were central framing principles. Important elements of the citizens' rights toolkit were transparency (publication of key draft texts), regular meetings with the Member States and consultation with the key interest groups on both sides. The interest group, the3million, was consulted on the position of EU citizens in the UK. ${ }^{29}$ The umbrella organisation, British in Europe, was consulted on the interests of UK nationals living in the EU..$^{30}$ Both interest groups were formed in the context of Brexit, precisely for these reasons. ${ }^{31}$ This process of consultation was conveyed on social media with photos of the Chief Negotiator, Michel Barnier, meeting with both thezmillion and with British in Europe.

\section{$3 \quad$ Key Elements of the Withdrawal Agreement as Regards Citizens' Rights}

This process of draft texts, discussions and consultations led to Part Two of the Withdrawal Agreement - concerning citizens' rights. Compared to the list of EU citizenship rights above, the Agreement focusses on a limited number of rights: residence; the exercise of an economic activity as a worker or

28 Laffan, B. (2019). How the EU27 came to be. Journal of Common Market Studies 57 (S1), pp. $13-27,16-18$.

29 The 3million is the largest campaign organisation for EU citizens in the UK, formed after the $2016 \mathrm{EU}$ referendum. It is not party affiliated and does not take a position on whether the UK should leave or remain in the EU. It works with MPs and organisations across the political spectrum on the specific issue of protecting EU citizens' rights. Available at https://www.the3million.org.uk/about-us.

30 The coalition group, British in Europe, was created in early 2017 to allow for better coordination between British citizenship groups across Europe in the Brexit negotiations. It is made up of 10 groups, representing a membership of around 35 ooo Brits, working together to stand up for the rights of UK citizens in the EU and EU citizens in the UK. Available at https://britishineurope.org/who-we-are/.

31 Both organisations are entered in the EU Transparency Register, where further details can be found. 
self-employed person (including frontier workers); social security coordination; and certain acquired rights, including recognition of professional qualifications (including qualifications in the process of being recognised). The expectation of acquiring permanent residence in the host country after legal residence for a continuous period of 5 years is also protected. ${ }^{32}$ The Agreement makes clear that persons within its scope will enjoy life-long protection, for as long as they continue to meet the necessary conditions. ${ }^{33}$

\section{$4 \quad$ Personal Scope and Lawful Residence}

The defining feature of Part Two of the Agreement is its personal scope. This is what decides if you are protected by the Agreement or not. For Britons in the $\mathrm{EU}$, personal scope is defined (except as regards social security where a different scope is necessary) by Article 10, as applying to,

- "UK nationals who exercised their right to reside in a Member State in accordance with Union law before the end of the transition period and continue to reside there thereafter"; and

- "UK nationals who exercised their right as frontier workers" in one or more Member States in accordance with Union law before the end of the transition period and continue to do so thereafter".

The same approach to scope applies also to EU citizens in the UK. The scope is generous to the extent that it catches citizens who move to live in either the UK or in an EU state during the transition period. However, for both groups of citizens, only in the circumstances where a person can demonstrate a right of residence as defined by Union law (or meets the definition of frontier worker in the Agreement), are they protected. ${ }^{35}$

The EU legal acquis on having a "right of residence" is a dense and complicated patchwork of legislation and Court of Justice case-law. Most Member States no longer require EU citizens to have residence documents (known as registration certificates) and many citizens may not know if they have a legal right of residence. The existence of the right is assessed based on compliance with certain conditions. As citizens' and their family members' factual situations evolve (e.g. in work or not, length of time unemployed, divorced, in

32 Article 15 of the Agreement.

33 Article 39 of the Agreement.

34 The term, "frontier worker" covers both employed and self-employed persons: see Article 9(b) of the Agreement.

Other than in relation to social security coordination, where a different scope applies. 
partnership or married, claiming benefits or not), they may cease, sometimes temporarily, to meet those conditions. Member State administrators find the law complex and are generally encouraged to take a strict approach to the determination of such rights. ${ }^{36}$ Member State authorities regularly challenge the right to reside of workers by asking the question whether the work was genuine and effective ${ }^{37}$; for the self-employed, ${ }^{38}$ Member State authorities apply a range of national criteria to recognise this status; and for non-active persons (for example, the retired), the lack of guidance on the meaning of "comprehensive sickness insurance" ${ }^{39}$ and the requirement for sufficient resources ${ }^{40}$ give Member State authorities various possibilities to find that residence was not "in accordance with Union law". Indeed, research on Britons in France mapped the case of Britons who, concerned about their status after the Brexit vote, applied for registration documents to confirm their right of residence, but ended up being served with papers asking them to leave France. ${ }^{41}$

The Joint Report from the negotiators in December 2017 already made clear there would be a pre-condition of legal residence in the Agreement. Thezmillion, British in Europe and academic commentators expressed considerable concern on this matter. ${ }^{42}$ The draft Withdrawal Agreement published in February 2018 maintained the condition, but softened its application with procedural provisions, requiring, for example: the application form to be

36 O'Brien, C. (2017). Unity in Diversity: EU Citizenship, Social Justice and the Cautionary Tale of the UK. Oxford: Hart Publishing, pp. 201-241.

37 O'Brien, C. (2016). Civis Capitalist Sum: Class as the New Guiding Principle of EU Free Movement Rights. Common Market Law Review 53 (4), pp. 937-978, 953-964; FEANTSA (2019). The working poor and EU free movement: the notion of "worker" in the context of low-wage and low-hour employment, available at https://www.feantsa.org/en/report/2019/ 05/22/the-working-poor-and-eu-free-movement-the-notion-of-worker-in-the-context-of-lowwage-and-low-hour-employment.

38 Guidance in EU law on who is self-employed is provided by Court of Justice, judgment of 27 June 1996, case C-107/94, Asscher, para. 26; and judgment of 30 November 1995, case C-55/94, Gebhard, paras. 24-25.

39 Although see Case C-535/19, pending before the Court of Justice.

40 Recent case-law from the Court of Justice gives Member States a basis to find persons, who claim "social benefits", do not comply with the requirement for sufficient resources and hence have no right to reside: Court of Justice, judgment of 19 September 2013, case C-140/12, Brey; judgment of 11 November 2014, case C-333/13, Dano.

41 Benson, M. (2019). "Focus: Brexit and Rethinking the British in Europe". Discover Society 65 Focus. See also, European Citizen Action Service (ECAS). UK and EU citizens still struggle to obtain residence documents in France, available at https://ecas.org/ uk-and-eu-citizens-still-struggle-to-obtain-residence-documents-in-france.

42 British in Europe and the3million (2018a). Securing citizens' rights: Considerations for Phase 2 of the Brexit negotiations, January 2018, avaible at https://docs.wixstatic.com/ugd/ od3854_3e2adebo77oa4e71b7d46o957afbeg26.pdf. 
"user-friendly"; that the competent authorities should "help the applicant to prove their eligibility"; 43 and underlining that the host state cannot require documents that "go beyond what is strictly necessary and proportionate to provide evidence".44

Less restrictive approaches to scope and to residence were indeed possible. ${ }^{45}$ Smismans suggests part of the reason behind the requirement for a right of residence may have been the fear of undermining the method of Directive 2004/38/EC ("the Free Movement Directive"), the central plank of EU law on the right of residence. ${ }^{46}$ Laffan, in her discussion of the overall EU approach, provides the rationale for this: one of the key strategies in the negotiations was to ensure adherence to, and preserve, the fundamental principles of the Union. ${ }^{47}$ Smismans argues, nonetheless, that simply copying the criteria for legal residence from the Free Movement Directive underestimates the challenges of applying these criteria in a very different context. ${ }^{48}$

The Requirement to Apply for Residence Status under the Agreement

During the Brexit negotiations, the United Kingdom made clear its intention to require EU citizens residing in the UK to apply for a status referred to as "settled status" in order to have rights in the UK under the Withdrawal Agreement. Following the framing principle of reciprocity, this meant that the EU Member States would have to require Britons in the EU to apply also for a new residence status. Adoption of this approach was controversial as it ran contrary to the usual "declaratory" approach in EU law, under which residence rights flow directly from EU law, regardless of whether the holder is in possession of a valid

43 Article 18(1)(o) of the Agreement.

44 Article 18(1)(n) of the Agreement.

45 See for example the concept of habitual residence in Article 11 of Regulation (EC) No 987/ 2009 laying down the procedure for implementing Regulation (EC) No 883/2004 on the coordination of social security systems, OJ L 284, 30.10.2009, p. 1, or the concept of normal residence in Council Directive 83/182/EEC of 28 March 1983 on tax exemptions within the Community for certain means of transport temporarily imported into one Member State from another, OJ L 105, 23.4.1983, p. 59.

46 Directive 2004/38/EC, cit.; Smismans, S. (2018). Brexit and EU27 citizens' rights: a proposal for a Protocol. EUlawanalysis Blog, available at https://eulawanalysis.blogspot.com/ 2018/o6/brexit-and-eu27-citizens-rights.html.

47 Laffan, B. (2019), cit., p. 17.

48 Smismans, cit. 
residence document. ${ }^{49}$ Moreover, it implied a potential administrative burden for EU Member States with large numbers of British residents.

In the end, the UK's requirement that EU citizens apply for "settled status" was accepted. Article 18(1) of the Agreement reflects this and allows the UK and the EU Member States to choose whether they will require EU citizens, UK nationals and their family members to apply for a new residence status or not. The principles of reciprocity, uniformity and indeed the declaratory nature of EU rights were therefore compromised on this point.

The UK started to implement its system of "settled status" in March 2019, well in advance of Brexit taking place. For Britons in the EU, Article 18(1) of the Withdrawal Agreement means there is no uniform EU approach to confirming their status in their country of residence under the Withdrawal Agreement. Each EU Member State decides whether to institute a "constitutive" registration system (similar to UK "settled status"), or whether to adopt the "declaratory" approach that legal residence on its territory is sufficient to be protected by the Agreement. ${ }^{50}$ At the time of writing this (April 2020), little information and no official published list is available: ${ }^{51}$ Italy has indicated it intends to apply the "declaratory approach", under which UK nationals and their family members must simply register their status. Austria, France and Greece, on the other hand, have indicated the adoption of a "constitutive" approach, requiring Britons to re-apply for a new residence status. ${ }^{52}$

The inclusion of an application procedure in the Agreement continues to cause controversy, particularly in the UK where this is the confirmed approach. ${ }^{53}$ The overall implication is that, if a person does not make an application within the required deadline, she loses her right to reside legally in the host state. ${ }^{54}$ Particular groups have been identified as at risk: elderly

49 Court of Justice, judgment of 8 April 1976, case C-48/75, Royer; judgment of 21 July 2011, case C-325/o9, Dias, paras. 48-49.

$5^{\circ}$ In the latter case, Article $18(4)$ of the Agreement provides for UK nationals to receive a residence document, which may be in a digital form, that evidences their status under the Agreement.

51 See Benton, M. \& Ahad, A. (2019), A. On the Brink: Prospects for UK Nationals in the EU-27 after a No-Deal Brexit. MPI Europe Policy Brief No.14, pp. 4-6.

52 British in Europe (2020). Newsletter, 15 April 2020.

53 The Commission's Chief Negotiator, Michel Barnier, wrote in December 2019 to the UK government to express concern about the deadline imposed for applications to be received. Brussels Uneasy over EU Citizens' rights after Brexit. Financial Times, January 8,2020 .

54 Smismans, S (2019). This is how to stop Brexit causing a new Windrush Scandal for EU citizens. Free Movement Blog, available at https://www.freemovement.org.uk/ this-is-how-to-stop-brexit-causing-a-new-windrush-scandal-for-eu-citizens. 
people; people without digital literacy; and children, who need their parents or guardians to apply on their behalf. ${ }^{55}$ Taken together with the need to prove compliance with the conditions for a right of residence under EU law, there is effectively a double burden on the applicant. Decades of residence, of work and real links to the country ${ }^{56}$ are potentially at risk. ${ }^{57}$ In response to these concerns, the negotiators inserted a provision in the Agreement that requires both the UK and the EU Member State authorities to assess all the circumstances in the case of applicants who do not apply within the deadline. The authorities are required to allow the application, if there are reasonable grounds for the failure to meet the deadline. ${ }^{58}$ There is also a requirement for the UK and the EU to carry out awareness-raising campaigns through national and local media. ${ }^{59}$ The UK government announced in summer 2019 funding for organisations to help UK nationals with the application process. ${ }^{60}$

In addition, for applicants who already hold a permanent residence document issued either under EU or under national law, the procedure is lighter: they have a right to exchange this for the new residence document, although must still confirm their "ongoing residence" and undergo checks to verify their identity and criminality and security checks. ${ }^{61}$ Citizens who have a permanent residence document, may however not know that a second application under the Withdrawal Agreement is necessary and information to this group of Britons in the EU - where some Member States will require applications and others not - will be particularly important. ${ }^{62}$

55 Sumption, M. and Kone, Z. (2018). Unsettled Status? Which EU Citizens are at Risk of Failing to Secure their Rights after Brexit? Oxford: Migration Observatory.

$5^{6}$ See for example the case of a Portuguese woman, who had worked in a range of jobs (building, looking after the elderly, caring for children) and lived in the UK for 20 years, but whose application status under the Withdrawal Agreement (settled status) was refused, "Tearful woman pleads to stay in UK on live TV", The Guardian, Friday 30 August 2019.

57 O'Brien, C. (2019) Settled Status scheme for EU citizens risks being next Windrush. The Times, April 4, 2019.

58 Article 18(1)(d) of the Agreement.

59 Article 37 of the Agreement; For example, in autumn 2019 the UK Government advertised on social media to invite UK nationals living abroad to "citizens outreach" meetings in their member state of residence.

6o Available at https://www.gov.uk/government/news/3-million-grant-to-help-uk-nationals-ineu-for-brexit.

61 Article 18(1)(h) of the Agreement.

62 Seeking Settled Status and Permanent Residency. The UK in a Changing Europe, available at https://ukandeu.ac.uk/seeking-settled-status-and-permanent-residency. 
Part Two of the Agreement protects also the residence and rights to work of family members of UK nationals in the EU and EU citizens in the UK. ${ }^{63}$ As in the case of primary right-holders, family members must show they resided in the host state in accordance with Union law. Both "direct" family members within the meaning of Article 2(2) of the Free Movement Directive and "extended" family members, including partners in a durable relationship, whose entry and residence have been facilitated under Article 3(2) of the Free Movement Directive, are protected. Provision is also made for a right of residence for children born, or legally adopted, after the end of the transition period.

No protection is, however, provided for the right of UK nationals to return to the UK accompanied by their non-UK family members, referred to in shorthand as the Surinder Singh right. ${ }^{64}$ The extensive case-law on which the right is based involves EU citizens enforcing EU law - Article 45, Article 49 or Article 21 TFEU against their home state on the basis that they are returning after having exercised Treaty free movement rights. ${ }^{65}$ This means that the UK will - post-Brexit - be entitled to apply its domestic immigration rules to the family members of Britons returning from the $\mathrm{EU}$, potentially causing difficulties for the family to return to the UK. The UK Government however announced that Britons returning to the UK from the EU would, based on UK law, be permitted to bring their family members - where the relation began before Brexit - until 29 March 2022. ${ }^{66}$

\section{$7 \quad$ Loss of Market Citizenship}

The principal rights not protected by the Agreement for Britons in the UK are their EU rights to earn a living through employment or self-employment in another Member State, provide cross-border services ("market citizenship rights") and move freely across EU borders. ${ }^{67}$ An early draft of the Withdrawal

\footnotetext{
63 Article 10(1)(e) of the Agreement.

64 Court of Justice, judgment of 7 July 1992, case C-370/9o, Rv. Immigration Appeal Tribunal and Surinder Singh.

65 C-370/9o Singh, cit.; Court of Justice, judgment of 11 December 2007, case C-291/05, Eind, paras. 35-38; judgment of 12 March 2014, case C-456/12, O. and B., paras. 50-51; judgment of 12 July 2018, case C-89/17, Banger, paras. 32-34.

66 Available at https://www.gov.uk/guidance/advice-for-british-nationals-travelling-andliving-in-europe.

67 Although UK nationals resident in the Schengen Area will benefit, as do other thirdcountry nationals, from free movement in the Schengen Area. This is limited to go days
} 
Agreement contained an Article 32 - "scope of rights" - which set this out explicitly, but it was deleted in the final published agreement. ${ }^{68}$

Instead the Agreement is limited to protecting "past life choices". This framing principle is legally translated via Articles 9(c) and (d), which define the "host state" and "state of work". The result is that a Briton's right to work in the EU either as an employed person or self-employed person is protected, where this right is being exercised in the host state at the end of the transition period or, if the person is a frontier worker (either employed or self-employed) and pursues an economic activity as a frontier worker in a Member State before the end of the transition period and continues to do so thereafter. ${ }^{69}$ So, for example, a frontier worker with UK nationality, living in Belgium and working in France, will have her residence in Belgium and right to work in France protected. However, the option under EU law to take on a new job in another Member State is not protected..$^{70}$ Similarly, for example, self-employed UK nationals established in Austria at the end of the transition will be protected as regards their work in Austria, but will not under the Withdrawal Agreement have the possibility to change their operations and establish in Italy.

The provision of cross-border services is, moreover, not covered in any way. UK nationals, who before or at the point of Brexit earn their living by providing their services in various Member States - IT engineers or freelance interpreters for example - are not protected. In today's labour market and gig economy, this is a striking restriction. The removal of such rights and the possibility under EU law to change country of work or establishment has been little publicised to Britons who are potentially affected. ${ }^{71}$ Pending any agreement on the UK-EU

within any 180-day period: Article 6(1) Schengen Borders Code (Regulation (EU) 2016/399 on a Union Code on the rules governing the movement of persons across borders, $O J L 77$, 23.3.2016, p. 1).

68 Article 32 of the Draft Withdrawal Agreement, 28 February 2018 provided: "In respect of United Kingdom nationals and their family members, the rights provided for by this Part shall not include further free movement to the territory of another Member State, the right of establishment in the territory of another Member State, or the right to provide services on the territory of another Member State or to persons established in other Member States", TF5o (2018) 33 - Commission to EU27.

69 See Articles 24 and 25, read in conjunction with Article 9(c) and (d), of the Agreement.

70 In contrast, the right to change to work in Belgium would seem to exist as, based on Article 17 of the Agreement, both EU citizens and UK nationals are entitled to "change status" in the host state: therefore in the example given, the UK national who resides (as a non-active person) in Belgium could change her status to a worker. Article 17 would appear to permit her to enter the Belgian labour market at a later stage.

71 One exception is "The beautiful dream destroyed: Britons in EU on no-deal Brexit", The Guardian, 7 September 2019, available at https://www.theguardian.com/politics/2019/ sep/o7/britons-in-eu-no-deal-brexit. The UK Government in autumn 2019 started advertising on social media to alert UK service providers to the need to protect their rights. 
future relationship, Britons who regularly cross borders providing services as the way of making their living will, where they can, establish as a legal person under the legislation of a Member State or find other solutions based on national law. .

As already mentioned above, the political rights of EU citizenship are lost by UK nationals immediately after the UK leaves the EU. These are the rights to vote and stand in European Parliament elections, to vote and stand in local elections and to launch and participate in a European Citizens' Initiative. These rights are explicitly exempted from the transition and there are no provisions under the Withdrawal Agreement, for example, to protect the position of a British councillor sitting on a local council in Spain. These matters are left to national law to deal with.

In this regard, Spain and the UK signed a bilateral agreement enabling Spaniards in the UK and UK nationals resident in Spain to maintain their rights to vote and stand in local elections once the UK leaves the EU.72 The bilateral agreement also allows UK citizens residing in Spain to vote in European Parliament elections - this reflects the fact that it is for Member States to decide the electoral franchise for the European Parliament. ${ }^{73}$ Bilateral agreements on voting rights have also been made by the UK with Luxembourg ${ }^{74}$ and Portugal. ${ }^{75}$ In addition, the UK agreed a Memorandum of Understanding with Ireland that affirms a range of existing reciprocal rights between the two countries, including the right for their citizens to vote in both local and general elections. ${ }^{76}$

Other rights of EU citizenship listed in Article $20(2)(c)$ and (d) TFEU (consular protection, right to petition the European Parliament and to apply to the European Ombudsman), while protected during the transition, are not covered by the Withdrawal Agreement. UK nationals resident in the EU nonetheless retain post-Brexit rights to petition the European Parliament and to apply to

72 Spain and UK guarantee citizens' voting rights after Brexit, Financial Times, January 21, 2019.

73 Case C-145/o4 Spain v United Kingdom, ECLI: EU:C:2006:543 at paras. 77-78.

74 Available at https://www.gov.uk/government/news/treaty-on-voting-rights-signed-withluxembourg.

75 Available at https://www.gov.uk/government/news/voting-rights-treaty-secured-withportugal.

76 Memorandum of Understanding between the Government of the United Kingdom of Great Britain and Northern Ireland and the Government of Ireland concerning the Common Travel Area and associated reciprocal rights and privileges, 8 May 2019, para. 13. 
the Ombudsman based on Articles 227 and 228 TFEU, which extend the remit of these procedures to "any natural or legal person residing or having its registered office in a Member State". The right to petition the European Parliament could indeed be an important means for Britons in the EU to obtain assistance with enforcing their rights under the Withdrawal Agreement. Unlike in the UK, where an independent authority will (from the end of the transition period) monitor the implementation and application of the rights of EU citizens under the Agreement, ${ }^{77}$ there is no specific mechanism foreseen by the Withdrawal Agreement to assist UK nationals enforce their rights in the EU.78

The right to be protected from discrimination on grounds of nationality will be an important right all-round post-Brexit. For persons within the scope of the Withdrawal Agreement the right to equal treatment regardless of Member State nationality is conserved in a number of ways. There is a general provision of non-discrimination in Article 12 of the Agreement, which mirrors the wording of Article $18 \mathrm{TFEU}$. Its scope is limited to the citizens' rights part of the Agreement. Since, however, the coverage of citizens' rights is limited, so the scope of this equal treatment right seems also limited.

There is also in Chapter 1 of Title II a guarantee of equal treatment which mirrors Article 24 of the Free Movement Directive. This gives persons with permanent residence status full equal treatment rights in matters such as social assistance or student study grants. However, persons with lesser residence rights are subject to the standard exceptions of the Directive (no entitlement to social assistance, maintenance aid etc). For workers, the equal treatment provisions of Regulation 492/2011 on the free movement of workers are reproduced. ${ }^{79}$ As regards establishment, the Chapter on professional qualifications sets out that the recognition of professional qualifications (based on specified EU instruments and where this has taken place or been initiated before the end of the transition period) shall maintain its effects, including the right to

77 Article 159 of the Agreement.

78 Rights protected by the Withdrawal Agreement should be enforceable in national courts in the Member States, with the possibility to make preliminary reference to the Court of Justice. A specialised committee on citizens' rights is also foreseen in Article 165(1)(a) of the Agreement, but its role as regards implementation and application of UK nationals' rights in the Member States is not specified.

Article 24 of the Agreement. 
pursue a profession under the same conditions as nationals of the state concerned. ${ }^{80}$

Space does not permit a detailed consideration of the social security coordination provisions in Title III of Part Two of the Withdrawal Agreement. The personal scope of this Title is much wider than the residence title. It covers persons who have been subject to the social security legislation of either the UK or the EU. This scope is aimed at protecting past contributions, as well as persons still in cross-border situations.

One of the key concerns for many Britons in the EU related to continuing access to healthcare in their state of residence. The Withdrawal Agreement provides that the EU social security coordination rules will continue to apply to persons within its scope.$^{81}$ Among other things, this means that the principle of equal treatment, which includes equal conditions of access to healthcare with nationals, will still apply. ${ }^{82}$ In addition, the S1 Portable Document system will continue, subject to the proviso that the citizens "continue without interruption" to be in a UK-EU cross-border situation. ${ }^{83}$ In the course of 2020 the European Commission is expected to agree with the Member States a "Guidance Document" on the citizens' rights provisions in the Withdrawal Agreement. Such guidance could, among other issues, clarify how the term, "continue without interruption", should be implemented.

\section{Loss of EU Citizenship and Preparations for No-Deal by the EU}

For a significant time leading up to Brexit, there was uncertainty as to whether the UK would leave the EU on the basis of the Withdrawal Agreement or not. The

\footnotetext{
80 Articles $27-29$ of the Agreement.

81 Article 30 of the Agreement.

82 Article 4 of Regulation (EC) No 883/2004 concerning the coordination of social security systems, OJ L 200, 7.6.2004, p. 1.; see also Article 24(1)€ of the Agreement which gives the same social advantages to workers and their families.

83 Article $30(2)$ of the Withdrawal Agreement. The $S_{1}$ allows persons, (for example) insured in the UK (pensioners, frontier workers, posted workers and some other categories of persons who work in more than one Member State) to register with the healthcare authority in their host state and receive treatment as if they were insured in that country - see Articles 17, 24, 25 and 26 of Regulation (EC) No 883/2004.
} 
European Commission therefore embarked on a process of No-Deal planning, the so-called "Brexit Preparedness" work. Just as the withdrawal negotiations underlined the capacity of the EU "to disaggregate complex problems and forge shared understandings across the member states", 84 so too did this contingency planning.

The protection of citizens' rights was a plank of the Brexit Preparedness process and the citizens' lobby groups, thezmillion and British in Europe, were consulted additionally as part of this. However, despite repeated requests by thezmillion and British in Europe for special protection of citizens' rights in the case of No-Deal (for example, by concluding a limited agreement based on Part Two of the Withdrawal Agreement or part thereof), ${ }^{85}$ the EU maintained there could be no "mini-deal" on citizens' rights. A regulation to put in place limited contingency arrangements for the EU social security coordination rules was however adopted as part of the Brexit Preparedness process. ${ }^{86}$

Had the UK left the EU without an agreement, then UK nationals would have transformed overnight from EU citizens who enjoyed entry rights, residence rights, market freedoms and free movement rights into third-country immigrants needing residence and work permits and, in the worst-case scenario, entry visas. The "Brexit Preparedness" planning by the Commission therefore encouraged Member States to formulate in advance of the first Brexit deadline of 29 March 2019 their contingency plans for dealing with this loss of EU citizenship by UK nationals.

The EU, as part of its common immigration policy, has of course legal migration rules for third-country nationals entering and living in the EU. These EU norms sit however alongside national rules. If the EU has not acted, then it is national law that applies. Moreover, there is variable geometry in this area: Denmark does not participate in the EU's common immigration policy; and Ireland only sometimes (if it chooses to opt in). Without a Withdrawal Agreement or other specific EU rules on how to deal with this unique situation of collective loss of EU citizenship on their territory, it would therefore be national competence that would apply. A key feature of the Brexit Preparedness planning was therefore to coordinate the 27 different legal regimes to which UK nationals would be subject.

84 Laffan, B. (2019), cit., p. 16.

85 British in Europe and the3million (2018). The last mile on citizens' rights, available at https:// britishineurope.org/wp-content/uploads/2018/o9/Joint-position-paper-the3million-andBritish-in-Europe.pdf.

86 Regulation (EU) 2019/500 of the European Parliament and of the Council of 25 March 2019 establishing contingency measures in the field of social security coordination following the withdrawal of the United Kingdom from the Union, OJ L 85I, 27.3.2019, p. 35 . 
One aspect of this planning was the provision of guidance to the Member States on the application of the Long-Term Residence Directive ("the LTR Directive"), a core instrument within the EU common immigration policy aimed at giving security of residence and a set of uniform rights to third-country nationals residing in EU Member States. ${ }^{87}$ In early discussions on No-Deal and residence, it had been widely assumed that Britons with EU permanent residence rights (for which 5 years of legal residence are required $)^{88}$ could simply fall back on the rights given (again after 5 years of legal residence) by the LTR Directive. However, when examined in detail, the LTR Directive allows Member States to define legal residence under their national law (albeit within the limits of EU law). ${ }^{89}$ Thus, residence in accordance with the Free Movement Directive could not automatically equate with legal residence for third-country nationals under national law. In addition, the LT R directive allows Member States to attach additional conditions to long term resident status, for example, compliance with integration conditions. ${ }^{90}$

The European Commission acknowledged the difficulties on this question in its Communication of 13 November 2018 on Contingency Planning and urged Member States to take "a generous approach to the rights of UK citizens who are already resident in their territory" and to treat periods of legal residence of UK citizens in an EU Member State before the withdrawal of the UK as periods of legal residence in a Member State in accordance with the LTR Directive. ${ }^{91}$

\section{Publication of Member State No-Deal Planning for Loss of EU Citizenship}

Beyond this guidance, the Commission coordinated meetings with the Member States and encouraged them to adopt No-deal legislation and publish information on UK citizens' rights. The Commission itself published an evolving

\footnotetext{
$87 \quad$ OJ L 16, 23.1.2004, p. 44 .

88 Article 16 of the Free Movement Directive.

89 European Commission (2011). Report from the Commission to the European Parliament and to the Council on the application of Directive 2003/109/EC concerning the status of thirdcountry nationals who are long-term residents. СОм (2011) 585 final, p. 2.

$90 \quad$ Article $5(2)$ of the long-term residents' Directive.

91 European Commission (2018). Preparing for the withdrawal of the United Kingdom from the European Union on 30 March 2019: a Contingency Action Plan. СОМ (2018) 880 final.
} 
overview of Member States' national No-Deal preparations on citizens' rights on its Brexit-preparedness website. ${ }^{92}$ The website underlined that national authorities of the Member States remained the first point of contact for UK nationals as regards No-Deal and links to relevant national websites were also provided. Nonetheless, the information presented by most Member States was clearly based on a standard text, although a variation of approaches among them was still noticeable.

The last published overview of these contingency arrangements (17 October 2019) showed that most Member States proposed a "transitional" or "grace period" in case of No-Deal, varying between 6 months to 3 years, to allow UK nationals time to adjust to their new status and apply for a residence status under national law. During this period, some countries proposed a specific temporary permit. Most countries proposed that UK nationals could keep during this period "most of their rights as EU citizens" in their host country, including the right to reside, work, look for a job or study. Family members, provided the relationship predated the withdrawal of the UK from the EU, also retained their rights.

After the end of the national transitional or grace period, the 27 Member States' approaches varied however:

(1) Some Member States took the approach that UK nationals were no different from any other third-country nationals and were required to apply for a residence permit under the general immigration regime for thirdcountry nationals (eg. Czech Republic, France, Germany);

(2) Others were less clear and either said nothing or referred to the need to apply for a new residence permit, according to the law that would be applicable at that time (eg. Belgium, Spain; Sweden);

(3) Some referred to UK nationals keeping their residence rights and "most of their rights" indefinitely (eg. Italy, Malta);

(4) Some Member States referred to laws that made specific provision for UK citizens to keep their residence rights on more favourable terms (eg. Lithuania), or to UK nationals and their family members preserving their status (Estonia);

(5) Most Member States set out that UK nationals with documents certifying permanent residence would qualify for long-term resident status without any further conditions (but not Ireland or Denmark);

(6) Others referred to conditions for granting permanent residence under national law (Slovakia; Finland). 
Many countries made clear that the arrangements offered for UK nationals were contingent on reciprocal treatment granted in a No-Deal situation to their own citizens living in the UK. ${ }^{93}$

In sum, the approach taken to the loss of EU citizenship pursuant to Nodeal covered a wide spectrum, with some Member States apparently prepared to recognise for UK nationals living in the EU a special status as former EU citizens and others not.

\section{Reflections on the Collective Loss of EU Citizenship}

\subsection{What Rights to Protect?}

A key question not addressed so far is what rights and interests should be protected when a Member State withdraws from the Union? What guidance is there in either EU law or in international law on protection of citizens' rights in this situation?

The Treaty itself - beyond the bare bones of Article 50 TEU - does not address what should happen to citizens' rights when a Member State withdraws. ${ }^{94}$ It is therefore a matter of interpretation how EU law should apply in such circumstances. Kostakopoulou, writing following the outcome of the historic UK vote to leave the EU, draws from the essence of EU citizenship a duty on the Union to protect its citizens in the situation where a Member State decides to withdraw. She proposes the idea of an "EU protected citizen status", which could apply both to EU citizens in the UK and to UK nationals in the EU. This would allow all EU citizens affected by Brexit to continue to be subject to the same conditions relating to their residence, employment and family reunification as previously. ${ }^{95}$ Garner underscores the need for reciprocal protection of rights and suggests an "ex-EU citizenship" regime for UK nationals living in the EU: "a Member State could operate as a legal guardian of an ex-EU citizen", complying with the Member State's obligation under Article 47 of the Charter

93 British in Europe (2019). Written evidence submitted by British in Europe to the House of Commons Committee for Exiting the European Union, NEGoo38.

94 Eeckhout and Frantziou point out that, at the Constitutional Convention that led to the Lisbon Treaty and the drafting of Article 50 TEU, some delegates proposed amendments that safeguarded existing rights, but these were not adopted: Eeckhout, P. and Frantziou, E.(2017). Brexit and Article 5o: A Constitutionalist Reading. Common Market Law Review 54 (3), pp. 695-733, 718. I am grateful to Nathan Cambien for this point.

95 Kostakopoulou, D. (2018). Scala Civium: Citizenship Templates Post-Brexit and the European Union's Duty to Protect EU Citizens. Journal of Common Market Studies 56 (4), pp. $854-869,863-866$. 
of Fundamental Rights to provide individuals with effective judicial protection. He also emphasises the possible role of the principle of "protection of legitimate expectations". ${ }^{96}$ Cambien refers to the "effet utile" of the EU right: by suddenly taking the right away, it could be argued that this compromises the effet utile of the right which happened in tempore non suspecto. ${ }^{97}$

There has also been debate on the impact of international law on the withdrawal of EU citizenship. Authors of a study for the European Parliament's Constitutional Affairs Committee took the view that residence rights and rights linked to the exercise of single market freedoms could not be considered "acquired rights", that is, rights protected against changes in law, under international law. ${ }^{98}$ The authors underlined at the same time the application of the European Convention on Human Rights: Article 8 concerning the right to respect for private and family life and one's home; and Article 1 of Protocol 1 concerning the right to property. They recommended therefore the conclusion of an agreement founded on reciprocity and non-discrimination that achieved for affected citizens "as close as possible enjoyment ... of the rights that European citizens have possessed until now", including "freedom of movement and residence, the so-called four freedoms, and equal access to public services and social protection, as well as the right to vote in municipal elections in the country of permanent residence". ${ }^{99}$ A study undertaken for Jill Evans MEP took a different view on the application of international law but made similar recommendations. The authors argued that the objectives of legal certainty and non-retroactivity of Article $70(1)(b)$ of the Vienna Convention on the Law of Treaties required that individual rights created in the execution of a treaty continue past its end. ${ }^{100}$ They concluded therefore that the rights of EU citizenship, where they were being exercised, could not be taken away and proposed that the Withdrawal Agreement should protect a form of "Continuity

96 Garner, Oliver. (2016). After Brexit: Protecting European citizens and citizenship from fragmentation. EUI Working Papers Law 2016/22, pp. 16-18; Note the principle of protection of legitimate expectations is a general principle of EU law: see for example, Court of Justice, judgment of 28 April 1988, case $120 / 86$, Mulder.

97 See Cambien, N. (2020). Residence Rights for EU Citizens and their Family Members: Navigating the New Normal, in this volume, section IV.2.

98 Fernandez Tomas A., and Lopez Garrido D. (2017). Study for the AFCO Committee: The Impact and consequences of Brexit on acquired rights of EU citizens living in the UK and British citizens living in the EU-27.

99 Ibid, p. 6o.

100 Roeben, V., Snell, J., Minnerop P., Telles, P., and Bush K. (2017). The Feasibility of Associate EU Citizenship for UK citizens post-Brexit: A study for Jill Evans MEP. DOI: 10.2139/ ssrn.3178o55, pp. 18-21. 
Union Citizenship", or indeed go further and create a new status of "Associate Union citizenship".

The idea of associate citizenship was also put forward by Charles Goerens MEP, who proposed, with a view to the future UK-EU relationship, associate EU citizenship for nationals of former Member States, "who feel and wish to be part of the European Project". ${ }^{101}$ The idea provoked however a counterreaction. Van der Mei suggested that such a new status, existing in parallel to full EU citizenship, could undermine EU citizenship. ${ }^{102}$ Van den Brink and Kochenov also objected to offering a form of EU citizenship to people who no longer had nationality of a Member State. The starting position for the negotiations, they argued, must be to accept that EU citizenship is terminated for nationals of a withdrawing state. ${ }^{103}$

In this author's view, the debate about associate or continuing EU citizenship is a distraction. It's not the label that matters. Rather, the core issue is protecting people whose rights are withdrawn while they are exercising them or who are discriminated against on grounds of their nationality as a result of the withdrawal process. In this regard, it seems the key rights - both for Britons in the EU and for EU citizens in the UK - necessitating protection are: residence; residence of family members; family reunification; legitimate expectations; property; the right to earn a living; equality and non-discrimination on grounds of nationality; and legal redress in respect of all these rights.

The process of loss of EU citizenship also merits discussion. For those citizens affected, Brexit has been and remains a drawn-out process of uncertainty: will rights be withdrawn; if they are, what new rights (if any) will be given in their place; where is information available; is an application for a new residence status necessary; what procedure should be followed; what documents are needed to prove legal entitlement to continue residing in their home: will the

\footnotetext{
101 European Citizens' Action Service (eCAS). Interview - Charles Goerens: We should never say no to Associate Citizenship. December 21, 2017, available at https://ecas.org/ charles-goerens-brexit-interview.

102 Van der Mei, A. (2018). Brexit and Citizenship II: Associate EU Citizenship, Maastricht University Law Blog, available at https://www.maastrichtuniversity.nl/blog/2018/10/ brexit-and-citizenship-ii-associate-eu-citizenship.

103 Van den Brink, M., and Kochenov, D. (2019). Against Associate EU Citizenship. Journal of Common Market Studies 57 (6), pp. 1366-1382.
} 
application be accepted?104 All these questions arise for both EU citizens in the UK and Britons in the EU. In addition, the split process between withdrawal, on the one hand, and the negotiation of the new UK-EU relationship, on the other, means an extended period for citizens affected by Brexit of not knowing what its impact on their lives will be. ${ }^{105}$

There is also the question of who exercises the duty of care for EU citizens affected by the departure of a Member State. In the Brexit negotiations the EU was clear throughout that securing the interests of EU citizens in the UK was its priority. Clearly it never took responsibility for the interests of the UK, ${ }^{106}$ nor for Britons in the EU. The UK government, focussing on the rights of EUcitizens in the UK, took however decisions, the reciprocal effect of which were not in the interests of Britons in the EU. The involvement of a neutral arbiter in the exit negotiations may arguably have obtained better results all round for the over 5 million citizens concerned.

What role did the European Parliament play? Via its Brexit Steering Group, it followed and gave input into the negotiations on citizens' rights. In its resolution of January 2020, the Parliament flagged a range of concerns on the implementation and monitoring of the citizens' rights part of the Agreement. The resolution called on the 27 Member StatesEU to provide legal certainty for UK nationals and included a commitment that the Parliament would monitor closely how they implement the possibility to require UK nationals living on their territory to apply for a new residence status. ${ }^{107}$

\section{$16 \quad$ Conclusions}

Brexit has underlined that EU citizenship remains a highly contingent status, reliant on nationality of a Member State. The nationals of a departing state

\footnotetext{
104 A survey of 3,044 people by Europe Street News underlined the anxiety and information gap felt by mobile EU citizens as a result of Brexit, European Street News (2019). Brexit, the EU and You, available at https://europestreet.news/brexit-the-eu-and-you-lack-of-informationprotection-and-political-representation-revealed-in-europe-street-news-survey.

105 Examples of the effects of this uncertainty are set out in the following article: https:// www.theguardian.com/politics/2019/nov/15/job-hunting-britons-in-eu-say-brexit-istaking-its-toll.

106 Laffan, B. (2019), cit., pp. 21-22.

107 Resolution on implementing and monitoring the provisions on citizens' rights in the Withdrawal Agreement adopted 15 January 2020, P9_TA-PROV(2020)ooo6: see points 14-16; see also the response of the European Parliament on Citizens' Rights and the Withdrawal Agreement in: European Parliament (2018). Resolution of 14 March 2018 on the framework of the future EU-UK relationship P8_TA-PROV(2018)oo69.
} 
living on the territory of the EU become once more "resident aliens" albeit, thanks to the Withdrawal Agreement, resident aliens with a special status. The hard default to third-country national status, which some Member States favoured in the context of No-deal preparations, is avoided. The Union has, to use Kostakopoulou's terminology, ${ }^{108}$ exercised its duty to protect.

Whether the protection given by the Agreement is optimal is a different question. For both EU citizens in the UK and UK nationals in the EU, obtaining the protection of the Agreement will be difficult due to the highly conditional nature of the right of legal residence in EU law and the generally restrictive approach national adminstrations take to recognising it. Moreover, the option given to both the UK and the EU Member States to require an application for protected status compounds the difficulties in obtaining the protection of the Agreement. Excellent information campaigns combined with dedicated advice and problem-solving services for affected citizens will all be vital for ensuring correct application and maximising the protection of the Agreement.

The Agreement does not protect all rights. The refusal by the EU in particular to protect the right of Britons living in the EU to free movement to other Member States and associated market citizenship rights in the Withdrawal Agreement was a key strategic move. It is a bitter blow for Britons living in the EU to lose these rights. While the creation of EU citizenship was intended to move beyond market citizenship, Brexit underlines that market citizenship - the right of individuals to move within the single market to earn a living through employment, self-employment and providing cross-border services remains indeed a fundamental aspect of EU citizenship.

Finally, process is important. The uncertainty of over three years about loss of rights and status has been harrowing for those affected. While there may be reluctance to plan for the possibility that another Member State could leave the Union, it might make sense to strengthen the "unfinished institution"109 of EU citizenship for the future. As the planning for a Conference on the Future of Europe with involvement of citizens commences, ${ }^{110}$ perhaps one of the topics to be addressed at this Conference should be the process of collective loss of EU citizenship?

\footnotetext{
108 Kostakopolou, D. (2018), cit.

109 Kostakopoulou, D. (2014), cit., p. 71.

110 European Commission (2020). Shaping the Conference on the Future of Europe COM(2020) 27 final.
} 